\title{
Utilization of the Alkaline White Mud as Cement-Based Materials for the Production of Cement
}

\author{
Shaoqi Zhou ${ }^{1,2,3 *}$, Yiming Lin ${ }^{1,3}$, Jingjing Zhao ${ }^{1,3}$, Songfeng Zeng ${ }^{4}$ and Jianhua Zhou ${ }^{4}$ \\ ${ }^{1}$ College of Environmental Science and Engineering, South China University of Technology, Guangzhou 510640, China \\ ${ }^{2}$ State Key Laboratory of Subtropical Building Science, South China University of Technology, Guangzhou 510641, China \\ ${ }^{3}$ Key Laboratory of Environmental Protection and Eco-remediation of Guangdong Regular Higher Education Institutions, South China University of Technology, \\ Guangzhou Higher Education Mega Center, Guangzhou 510006, PR China \\ ${ }^{4}$ Guangdong South Solda Industry, Co Ltd, Nangang West 488, HuanPu District, Guangzhou 510760, PR China
}

\begin{abstract}
The effects of using alkaline white mud as substitutes for cement property in the process of clinker burning were investigated in this paper. Samples were prepared with adding $0.5-5.0 \%$ of alkaline white mud as substitutes for unit raw meal and then these mixtures were burned at $1450^{\circ} \mathrm{C}$ for $2 \mathrm{hrs}$. The results showed that the compressive strength and flexibility strength of the pastes were a little better than the plain sample. The concentrations of $\mathrm{MgO} \mathrm{SO}_{3}$ and chloride ions in clinkers were far below the limits in the standards when the addition of alkaline white mud was below the content of $5.0 \%$. The Results also showed that the concentrations of free lime were in a growing tendency with the increasing of alkaline white mud.
\end{abstract}

Moreover, the addition of AWM in raw meal increased the content of $C_{3} S$ phase in the clinker, something leading the increase of the setting times and enhances the strengths of the cement pastes in the early curing ages.

Keywords: Alkaline white mud (AWM); Clinker; Compressive strength; Particle-size; Hydration

\section{Introduction}

Alkaline white mud (AWM) is an inevitable waste material that is formed during the Solvay process. According to the published statistics [1], in 2006, $1.5 \times 10^{7}$ tons soda ash was produced and there was a growthing demand by $(1.4-1.5) \times 10^{6}$ tons per year. The increasing requirement for the soda ash coupled had caused an overproportional increase of huge quantities of waste products. In recent years, despite part of them being used in agriculture as organic fertilizer and soil management [1], the most common method to dispose AWM are sanitary landfills and in ocean [2,3]. However, after more stringent regulatory limits and with an increasing problem of changes in natural ecosystems, the ocean deposition has already been banned [1]. Moreover, the high cost of disposal and the increasingly difficult to find suitable landfill sites. In fact there is a need to find an alternative solution to dispose the AWM.

In the Solvay process, the alkaline white mud was produced from the limestone, which is used in the form of milk lime for the recovery of ammonia [3]. Interestingly, the limestone is also one of the main raw materials in the producing clinkers of ordinary Portland cement (OPC), so it is possible to concern that it can be used as substitutes for conventional cement and aggregates in concrete [4-6]. Moreover, the waste heat of kiln can be recycled to dry the AWM and their increasing emissions also can be controlled by the flue gas treatment system that has already been equipped in the cement plant. Furthermore, the method for using cement plant to dispose the AWM, which is expected greatly for protecting of environment by virtue of reducing the natural resources for cement and relieving the load to disposal sites.

In general, the reuse of a waste material in concrete production depends on several characteristics in it, several characteristics, for example chemical composition. Frequently, The main components in AWM include $\mathrm{CaCO}_{3}, \mathrm{CaSO}_{4}, \mathrm{Ca}(\mathrm{OH})_{2}, \mathrm{CaCl}_{2}$ and $\mathrm{Mg}(\mathrm{OH})_{2}$ and so on $[7,1]$. However, the mineral formation of clinkers with magnesium, sulfur and chlorine are harmful materials for the clinker. Consequently, the minerals formed by sulfate, chlorine and magnesium in the concrete producing processes should be taken into account and their contents must be detected.
In this study, our aim is to concern about the characteristic of cement clinkers by comparing the normal cement clinker, which were added AWM as substitutes for raw meals during the clinker production process. The flexural and compressive strengths and setting times of cement pastes, scanning electron microscope (SEM) micrographs, and the hydration characters of curing ages at 3,7 and 28 days of the clinkers were also investigated.

\section{Materials and Methods}

\section{Materials}

Alkaline white mud: Alkaline white mud used in the current study, is collected from a soda ash manufacturing plant located in the suburban area of Guangzhou city (South China). The plant has a capacity of producing 350,000 tons soda ash per year. The AWM was collected after it was concentrated by plate and frame filter press in the plant and then it was dried at $105^{\circ} \mathrm{C}$ for $48 \mathrm{hrs}$. Finally, the dried AWM was further pulverized in a ball mill (porcelain mill, XMCO- $\phi$ $280 \times 290$ ) until the particles could pass through a \# 200 mesh (with 75 $\mu \mathrm{m}$ pore diameter) metallic sieve and its chemical composition was characterized.

Raw materials: The limestone, iron, shale, fly ash, sand powders were collected from a cement plant in Guangzhou (South China). The plant has a potential production of 9000 tons' cement clinker per day. All the raw materials were over dried at $105^{\circ} \mathrm{C}$ for $24 \mathrm{hrs}$ and the chemical compositions were detected by using wavelength dispersion

*Corresponding author: Shaoqi Zhou, College of Environmental Science and Engineering, South China University of Technology, Guangzhou 510640, China Tel: +86 13560447169; E-mail: fesqzhou@scut.edu.cn

Received November 25, 2011; Accepted January 30, 2012; Published February 01,2012

Citation: Zhou S, Lin Y, Zhao J, Zeng S, Zhou J (2012) Utilization of the Alkaline White Mud as Cement-Based Materials for the Production of Cement. J Civil Environment Engg 2:108. doi:10.4172/2165-784X.1000108

Copyright: () 2012 Zhou S, et al. This is an open-access article distributed under the terms of the Creative Commons Attribution License, which permits unrestricted use, distribution, and reproduction in any medium, provided the original author and source are credited. 
$\mathrm{X}$-ray fluorescence spectrometer (XRF). The raw materials were further pulverized in a ball-mill until the particles could pass through a \# 200 mesh (with $75 \mu \mathrm{m}$ pore diameter) metallic sieve. And then all of them were well blended by according to the cement clinker ratios, which were calculated with the consideration of the Lime Saturation Coefficient:

$\mathrm{KH}=\left(\mathrm{CaO}-1.65 \mathrm{Al}_{2} \mathrm{O}_{3}-0.34 \mathrm{Fe}_{2} \mathrm{O}_{3} / 2.80 \mathrm{SiO}_{2}\right), 0.902<\mathrm{KH}<0.915$

the Silica Modulus:

$\mathrm{SM}=\mathrm{SiO}_{2} /\left(\mathrm{Al}_{2} \mathrm{O}_{3}+\mathrm{Fe}_{2} \mathrm{O}_{3}\right), 2.25<\mathrm{SM}<2.35$

the Iron Modulus:

$\mathrm{IM}=\left(\mathrm{Al}_{2} \mathrm{O}_{3} / \mathrm{Fe}_{2} \mathrm{O}_{3}\right), 1.30<\mathrm{IM}<1.40$

and the Lime Saturation

L.S.F $=\left(\mathrm{CaO} / 2.8 \mathrm{SiO}_{2}+1.18 \mathrm{Al}_{2} \mathrm{O}_{3}+0.65 \mathrm{Fe}_{2} \mathrm{O}_{3}\right), \quad 0.94<\mathrm{L} . \mathrm{S} . \mathrm{F}<0.96$ [8-10]. The oxide compositions of all the raw materials, including the AWM, and the mixed raw meal were shown in Table 1 and the particle size distribution analysis of raw meal was showed in Figure 1(a).

Cement clinkers: The cement raw meals were prepared by well mixing with various ratios of AWM/raw meal (by weight), which were $0: 100,1: 99,2.5: 97.5$ and 5:95, respectively. All the grounded raw mixtures were burned in a programmable electrical heated furnace to form cement clinkers. The high temperature furnace temperature was raised by $6^{\circ} \mathrm{C} \mathrm{min}-1$ from the room temperature and maintained at $1,450^{\circ} \mathrm{C}$ for $2 \mathrm{hrs}$, and then the resulting products were cooled rapidly in air. The next step is that, all the cement clinkers were further pulverized and grounded in a ball-mill until, most of them could pass through a \# 200 mesh (with $75 \mu \mathrm{m}$ pore diameter) metallic sieve (retained on mesh sieve was less than $5 \%$ in weight). After this step each sample of cement clinker was co-grounded with $5 \%$ and $15 \%$ per weight of gypsum and fly ash to produce its corresponding cement.

\section{Approach}

Molding and curing of cement mortar specimens: The mortar mixtures of the above four cements were prepared according to GB/T 17671-2007 (Standard test method for strength of hydraulic cement mortar of China). The ratio of sand/cement (by weight) was 3:1. The water to cement ratio was fixed at 0.50 . Mortars were put in a $(40 \times 40 \times 160) \mathrm{mm}$ molds for obtaining specimens and were stored in a moisture room $(20 \pm 1)^{\circ} \mathrm{C}$ for $24 \mathrm{hrs}$. And then all the specimens were demoulded and cured by immersion in a $(20 \pm 1)^{\circ} \mathrm{C}$ water bath for 3-28 days. Finally, the flexural strength and compressive strength development of specimens were measured after curing ages of 3, 7 and 28 days.

\section{Analyses}

Chemical and physical analyses of the cement clinkers, ordinary Portland cement and cement pastes were conducted as follows:

- Particle distribution test: Particle distribution test was carried out by a laser diffraction particle size analyzer (SALD-201, Japan) and the measure range is from 0.25 to $350 \mu \mathrm{m}$.

- Flexural strength and compressive strength test: GB/T 176712007.

- Setting time: The setting times of the cement mixes were measured according to GB/T1346-2001 (Test methods for water requirement of normal consistency, setting time and soundness of the Portland cements of China). This standard was similar to the ASTM C 191. The initial setting time was defined as when a Vicat needle $(1.13 \pm 0.05) \mathrm{mm}$ would penetrate the sample to a point $(4 \pm 1) \mathrm{mm}$ from the bottom of the mould and the final setting time was defined as when the Vicat needle would penetrate the sample to a point $0.5 \mathrm{~mm}$ [9].

- Mineralogy: The x-ray diffraction(XRD) analysis was conducted out by using a Bruker D8 Advance X-ray diffractometer with $\mathrm{Cu}$ Ka radiation and $2 \theta$ scanning ranging from $10^{\circ}$ to $70^{\circ}$. The

\begin{tabular}{|l|l|l|l|l|l|l|}
\hline $\begin{array}{l}\text { Chemical } \\
\text { composition }\end{array}$ & Limestone & Shale & Ferrate & Fly ash & Soda residue & Raw meal \\
\hline $\mathrm{LOl}^{\mathrm{a}}(\%)$ & 38.42 & 3.53 & 8.62 & 4.06 & 36.47 & 34.71 \\
\hline $\mathrm{SiO}_{2}{ }^{\mathrm{b}}(\%)$ & 7.19 & 75.43 & 37.05 & 45.30 & 2.78 & 8.35 \\
\hline $\mathrm{Al}_{2} \mathrm{O}_{3}{ }^{\mathrm{b}}(\%)$ & 1.68 & 12.04 & 16.13 & 36.99 & 2.02 & 2.69 \\
\hline $\mathrm{Fe}_{2} \mathrm{O}_{3}{ }^{\mathrm{b}}(\%)$ & 0.98 & 4.44 & 34.09 & 5.98 & 0.57 & 2.25 \\
\hline $\mathrm{CaO}^{\mathrm{b}}(\%)$ & 49.28 & 0.18 & 0.65 & 4.65 & 39.16 & 42.66 \\
\hline $\mathrm{MgO}^{\mathrm{b}}(\%)$ & 0.56 & 0.51 & 0.44 & 0.59 & 7.53 & 0.26 \\
\hline $\mathrm{K}_{2} \mathrm{O}^{\mathrm{b}}(\%)$ & 0.12 & 2.23 & 0.70 & 0.56 & 0.05 & 0.32 \\
\hline $\mathrm{Na}_{2} \mathrm{O}^{\mathrm{b}}(\%)$ & 0.08 & 0.32 & 0.09 & 0.26 & 1.15 & 0.11 \\
\hline $\left.\mathrm{SO}_{3}{ }^{\mathrm{b}} \%\right)$ & 0.45 & 0.02 & 0.55 & 0.24 & 4.22 & 0.38 \\
\hline $\mathrm{Cl}^{-\mathrm{b}}(\%)$ & 0.003 & 0.006 & 0.005 & 0.012 & 4.420 & 0.010 \\
\hline $\mathrm{Total}^{(0.5}$ & 98.76 & 98.70 & 98.32 & 98.64 & 98.37 & 97.98 \\
\hline
\end{tabular}

${ }^{a}$ Analyzed by muffle furnace at temperature $(950 \pm 25)^{\circ} \mathrm{C}$ ${ }^{\mathrm{b} A n a l y z e d}$ by XRF

Table 1: Chemical compositions of the raw materials and raw meal.
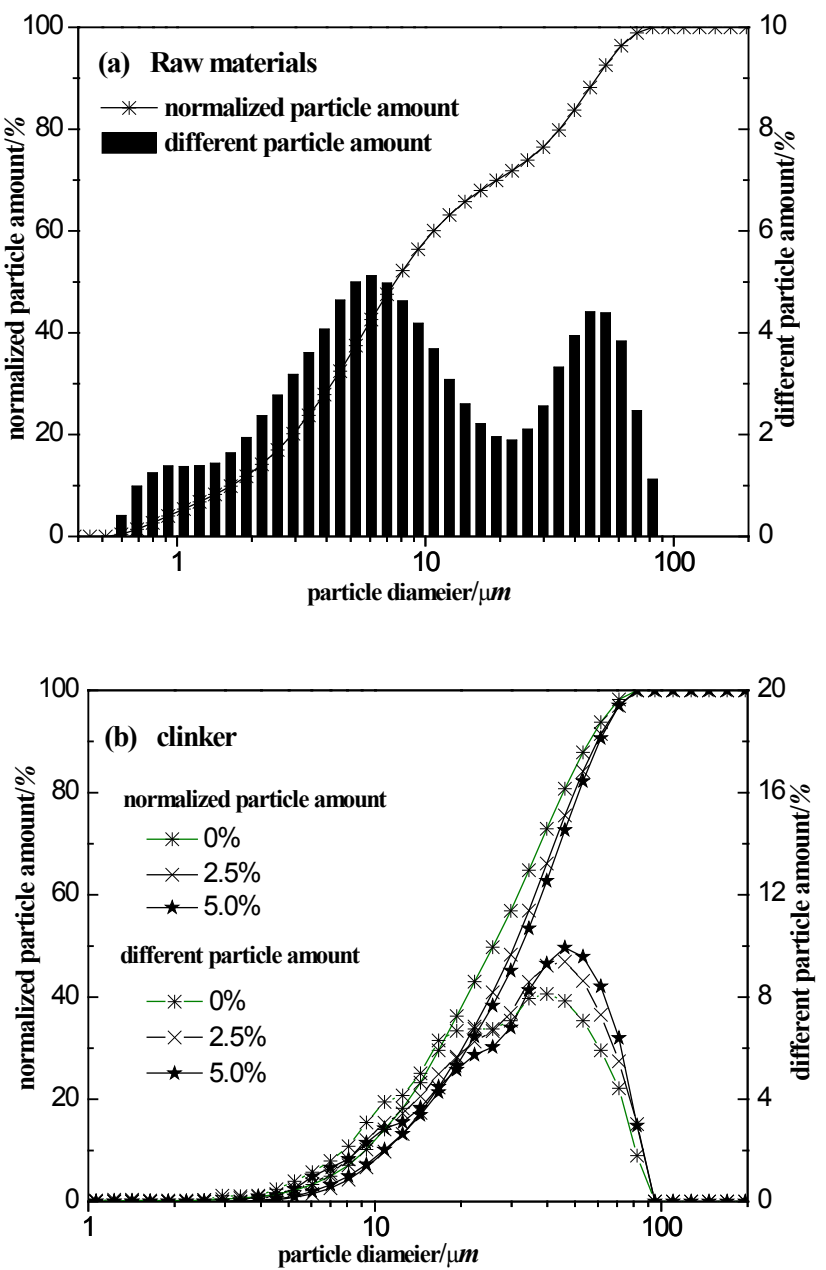

Figure 1: Particle size distribution of the raw meal (a) and cement clinkers (b) 
XRD scans were ran in $0.02^{\circ}$ steps, with a counting time of $17.7 \mathrm{~s}$.

- SEM: Several cement clinkers were investigated with an SEM (S-3700N, Hitachi Ltd of Japan).

- Chemical composition: The chemical compositions of the raw materials and raw meal were confirmed by using wavelength dispersion X-ray fluorescence spectrometer (XRF PANalytical Axios of Netherlands).

- Detection of chloride ions: A $2.50 \pm 0.002 \mathrm{~g}$ sample was placed in $250 \mathrm{ml}$ of beaker, and $25 \mathrm{ml}$ of distilled water and $25 \mathrm{ml}$ acid of $\mathrm{HNO}_{3}$ solution $\left(\mathrm{HNO}_{3}: \mathrm{H}_{2} \mathrm{O}=1: 2\right.$, by volume) was added to each beaker (included check sample). The samples were then treated by ultrasonic waves $\left(300 \mathrm{~W}, 80 \mathrm{KH}_{\mathrm{Z}}\right)$ under the water temperature at $50^{\circ} \mathrm{C}$ with an ultrasonic reflux rotator (KQ300VDE, Kun Shan of China). The slurries were filtered by using $0.45 \mu \mathrm{m}$ Certified Glass Fiber Filter. The leachates were decomposed by acid $\left(\mathrm{HNO}_{3}: \mathrm{H}_{2} \mathrm{O}=1: 100\right.$, by volume) and the specimen was analyzed by automatic potentiometric titration (CCQTC2006-4 chlorine ion detector, China).

- FTIR analysis: The hydration products and its changes with different AWM addition in raw clay of clinkers were analyzed with a Fourier Transform Infrared spectrometer (Nicolet 6700, USA). The samples were dehydrated by ethanol after curing ages at 3, 7 and 28 days, respectively, then it was dried at $80^{\circ} \mathrm{C}$ for $24 \mathrm{hrs}$ and finally was measured [11].

\section{Results and Discussion}

\section{Particle size distributions of raw meal and cement clinkers}

The size distributions of raw meal and three cement clinkers (the AWM contents were $0 \%, 2.5 \%$ and $5.0 \%$, respectively) were presented in Figure 1. As shown in Figure 1(a), the diameter of particles with percentages by volume less than $10 \%, 50 \%$ and $90 \%$ were $1.66,7.57$ and $49.3 \mu \mathrm{m}$, respectively. The maximum size of sample was $82.19 \mu \mathrm{m}$ and the particle size of the raw meal mainly distributed in $0.34-71.11$ $\mu \mathrm{m}$, which attained to the requirements of production of burning cement clinker (retained on 80 mesh sieves was less than 10\%). On the other hand, Figure 1(b) showed that the size distributions of three clinkers, the median diameter $\left(D_{50}\right)$ of the three cement clinkers were $25.92,30.72$ and $32.54 \mu \mathrm{m}$, respectively. In addition, the diameters in $0-30 \mu \mathrm{m}$ were $57.15,48.66$ and $45.47 \% ; 10-40 \mu \mathrm{m}$ were $61.24,58.36$ and $54.44 \%$; $30-60 \mu \mathrm{m}$ were $35.73,41.48$ and $43.63 \%$, more than $60 \mu \mathrm{m}$ were $7.12,9.86$ and $10.90 \%$, respectively. Moreover, the diameter less than $80 \mu \mathrm{m}\left(\mathrm{D}_{80}\right)$ of the three cement clinkers were 45.42, 49.75 and $51.55 \%$. Therefore, we drew a conclusion that the specific surface area of the clinkers were approximately from 350 to $600 \mathrm{~m}^{2} / \mathrm{kg}$ and the size distributions of raw meal and clinkers met the industrial requirements of production of cement.

\section{Cement clinkers composition}

The compositions of the three clinkers, which were substituted the raw meal of $0,2.5$ and $5.0 \%$ by AWM, and the OPC clinker used in this study was analyzed by XRF. The theoretical phase compositions were predicted using a modified Bogue calculation $\left[\mathrm{C}_{3} \mathrm{~S}=3.80 \mathrm{SiO}_{2}(3 \mathrm{KH}-2)\right.$; $\mathrm{C}_{2} \mathrm{~S}=8.61 \times \mathrm{SiO}_{2}(1-\mathrm{KH}) ; \mathrm{C}_{3} \mathrm{~A}=2.65 \mathrm{Al}_{2} \mathrm{O}_{3}-1.69 \mathrm{Fe}_{2} \mathrm{O}_{3} ; \mathrm{C}_{4} \mathrm{AF}=3.04 \mathrm{Fe}_{2} \mathrm{O}_{3}$; $\left.\mathrm{KH}=\left(\mathrm{CaO}-1.65 \mathrm{Al}_{2} \mathrm{O}_{3}-0.34 \mathrm{Fe}_{2} \mathrm{O}_{3} / 2.80 \mathrm{SiO}_{2}\right)\right]$ [1]. The results were shown in Table 2. It revealed that the main composition of $\mathrm{SiO}_{2}, \mathrm{CaO}$, $\mathrm{Al}_{2} \mathrm{O}_{3}$, and $\mathrm{Fe}_{3} \mathrm{O}_{4}$ were similar to those in the clinker of OPC. However, the amount of $\mathrm{SiO}_{2}$ and $\mathrm{Fe}_{3} \mathrm{O}_{4}$ decreased with the AWM addition, while the compositions of $\mathrm{CaO}, \mathrm{MgO}, \mathrm{Al}_{2} \mathrm{O}_{3}$ and $\mathrm{SO}_{3}$ increased. The contents of the $\mathrm{MgO}$ and $\mathrm{SO}_{3}$ could had an influence on the property of cement, but Table 2 showed that the contents of those ranged from 1.05 to $1.18 \%$, as well as 1.06 to $1.81 \%$, which were much less than the limitation value $\left(\mathrm{MgO} \leq 5.0 \%\right.$; $\mathrm{SO}_{3} \leq 3.5 \%$, ) of the Standards of $\mathrm{GB} 175$ 2007 (Common Portland Cement, China).

Table 2 also showed that the phase composition of $\mathrm{C}_{3} \mathrm{~S}$ in the clinkers when the raw meal was substituted with $5.0 \%$ of AWM were somewhat higher than those in the clinker of OPC, while the $\mathrm{C}_{2} \mathrm{~S}$ content was also lower than other clinkers. It indicated that this clinker could have a fast rate of hydration than other clinkers. However, it also could be seen that lime saturation coefficient $(\mathrm{KH})$ of was higher than others, so it might had a higher free lime content that others in the clinkers.

\section{f-cao and chloride ions contents in the clinkers}

Figure 2 presented the contents of the free lime and chloride ions in

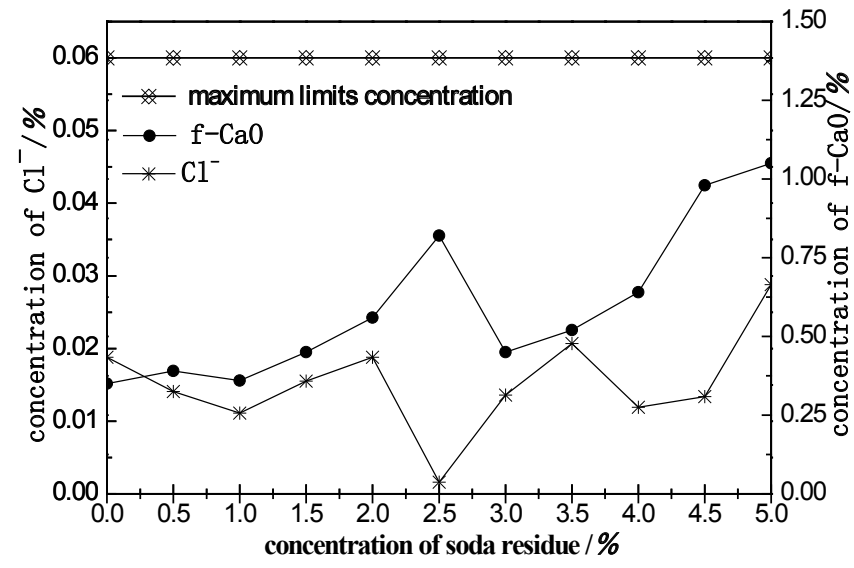

Figure 2: Changes of $\mathrm{f}-\mathrm{CaO}$ and chloride ions contents in the clinker.

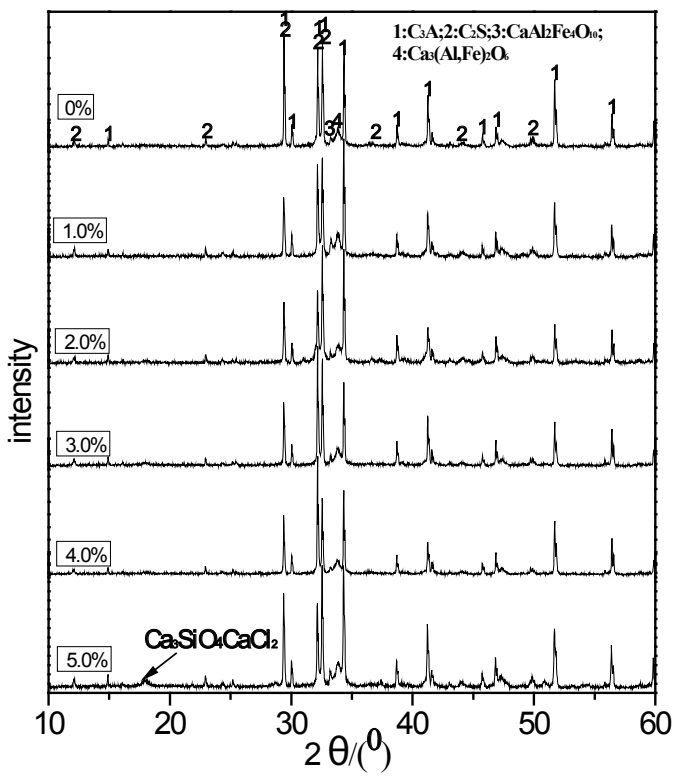

Figure 3: XRD patterns of clinkers 
Citation: Zhou S, Lin Y, Zhao J, Zeng S, Zhou J (2012) Utilization of the Alkaline White Mud as Cement-Based Materials for the Production of Cement. J Civil Environment Engg 2:108. doi:10.4172/2165-784X.1000108

Page 4 of 7

\begin{tabular}{|l|l|l|l|l|}
\hline Composition & OPC & Sample 1 & Sample 2 & Sample 3 \\
\hline $\mathrm{SiO}_{2}(\%)$ & 21.16 & 20.98 & 20.59 & 20.35 \\
\hline $\mathrm{AL}_{2} \mathrm{O}_{3}(\%)$ & 5.31 & 5.52 & 5.64 & 5.85 \\
\hline $\mathrm{Fe}_{3} \mathrm{O}_{4}(\%)$ & 3.85 & 3.93 & 3.84 & 3.77 \\
\hline $\mathrm{CaO}(\%)$ & 65.58 & 64.80 & 65.15 & 66.01 \\
\hline $\mathrm{MgO}(\%)$ & 1.09 & 1.05 & 1.15 & 1.18 \\
\hline $\mathrm{K}_{2} \mathrm{O}(\%)$ & 0.63 & 0.76 & 0.61 & 0.82 \\
\hline $\mathrm{Na}_{2} \mathrm{O}(\%)$ & 0.13 & 0.12 & 0.12 & 0.10 \\
\hline $\mathrm{SO}_{3}(\%)$ & 0.097 & 1.06 & 1.70 & 1.81 \\
\hline $\mathrm{Constituents}$ & & & & \\
\hline $\mathrm{C}_{3} \mathrm{~S}(\%)$ & 58.71 & 57.17 & 56.63 & 59.99 \\
\hline $\mathrm{C}_{2} \mathrm{~S}(\%)$ & 16.39 & 17.04 & 16.31 & 13.10 \\
\hline $\mathrm{C}_{3} \mathrm{~A}(\%)$ & 7.54 & 7.99 & 8.45 & 9.14 \\
\hline $\mathrm{C}_{4} \mathrm{AF}(\%)$ & 11.73 & 11.94 & 11.67 & 11.47 \\
\hline $\mathrm{Moduli}$ & & & & \\
\hline LSF (\%) & 0.953 & 0.943 & 0.956 & 0.974 \\
\hline $\mathrm{KH}(\%)$ & 0.910 & 0.906 & 0.908 & 0.925 \\
\hline $\mathrm{SIM}(\%)$ & 2.309 & 2.221 & 2.172 & 2.114 \\
\hline $\mathrm{ALM}(\%)$ & 1.376 & 1.405 & 1.469 & 1.551 \\
\hline
\end{tabular}

Table 2: Chemical compositions of the four sample clinkers.

the clinkers with addition of AWM. It showed that all the contents of chloride ions in the clinkers were lower than the values $(\leq 0.06 \%)$ of the maximum limits concentration of GB175-2007 (Standard of common portland cement of China). Thus, the results indicated that the chloride ions were vaporized during the melting process. In addition, Figure 2 also showed that the content of the free lime increased with the addition of AWM in the raw meal. From the previous discussion (3.2), the results could be attributed to the decreased contents of $\mathrm{SiO}_{2}$ and the increased contents of $\mathrm{CaO}$, because those changes could increase the melting temperature during the composing of clinkers. However, the results suggested that all the contents of free lime (Standard of China: less than 2.0\%) and chloride ions (Standard of Japan: $0.35 \%$, Standard of China: $0.06 \%$ and Standard of UK: 0.1) much lower than the maximum values of limits of the cement plants [12,13], so all the clinkers met the industrial requirements of production of cement.

\section{Characterization of the cement clinkers}

Figure 3 showed the X-ray diffraction (XRD) pattern results for the plain clinker and the six cement clinkers. The results indicated that the major components in the cement clinkers were $\mathrm{C}_{3} \mathrm{~S}\left[\mathrm{Ca}_{3} \mathrm{SiO}_{5}\right.$ and $\left.\mathrm{Ca}_{3}\left(\mathrm{SiO}_{4}\right) \mathrm{O}\right], \mathrm{C} 2 \mathrm{~S}\left[\mathrm{Ca}_{2} \mathrm{SiO}_{4}\right.$ and $\left.\mathrm{Ca}_{2}\left(\mathrm{SiO}_{4}\right)\right], \mathrm{C}_{3} \mathrm{~A}\left[\mathrm{Ca}_{3} \mathrm{Al}_{2} \mathrm{O}_{6}\right.$ and $\mathrm{Ca}_{3}(\mathrm{Al}$, $\left.\mathrm{Fe})_{2} \mathrm{O}_{6}\right], \mathrm{C}_{4} \mathrm{AF}\left(\mathrm{Ca}_{4} \mathrm{Fe}_{2} \mathrm{Al}_{2} \mathrm{O}_{10}\right)$ and all were similar to those in ordinary Portland cement. Moreover, the phase formation of $\mathrm{Ca}_{54} \mathrm{MgAl}_{2} \mathrm{Si}_{16} \mathrm{O}_{90}$ was identified in all the clinkers. However, the $\mathrm{Ca}_{3} \mathrm{SiO}_{4} \mathrm{CaCl}_{2}$ phase formation was detected in the clinkers, especially when the raw meal was replaced with $5.0 \%$ of AWM. Therefore, we confirmed that the addition of AWM as a part of raw meal could increase the content of chloride ions in the clinkers, whereas most of them were vaporized during the melting process.

\section{Microstructure of cement clinkers by SEM}

To verify the X-ray diffraction (XRD) pattern results for the clinkers, SEM examination was performed. Figure 4 showed the microstructure of clinkers with AWM contents of $0 \%$ (a), 2.5\% (b) and $5.0 \%$ (c). It was found that different amount of AWM replacement somewhat led to discrepancies in the microstructures of the clinkers. However, all the microstructures of the mixture were basically the same, so further study is needed in the next section.

Setting time and strength development of OPC paste and cement pastes

The setting times for the three pastes and the OPC paste were given
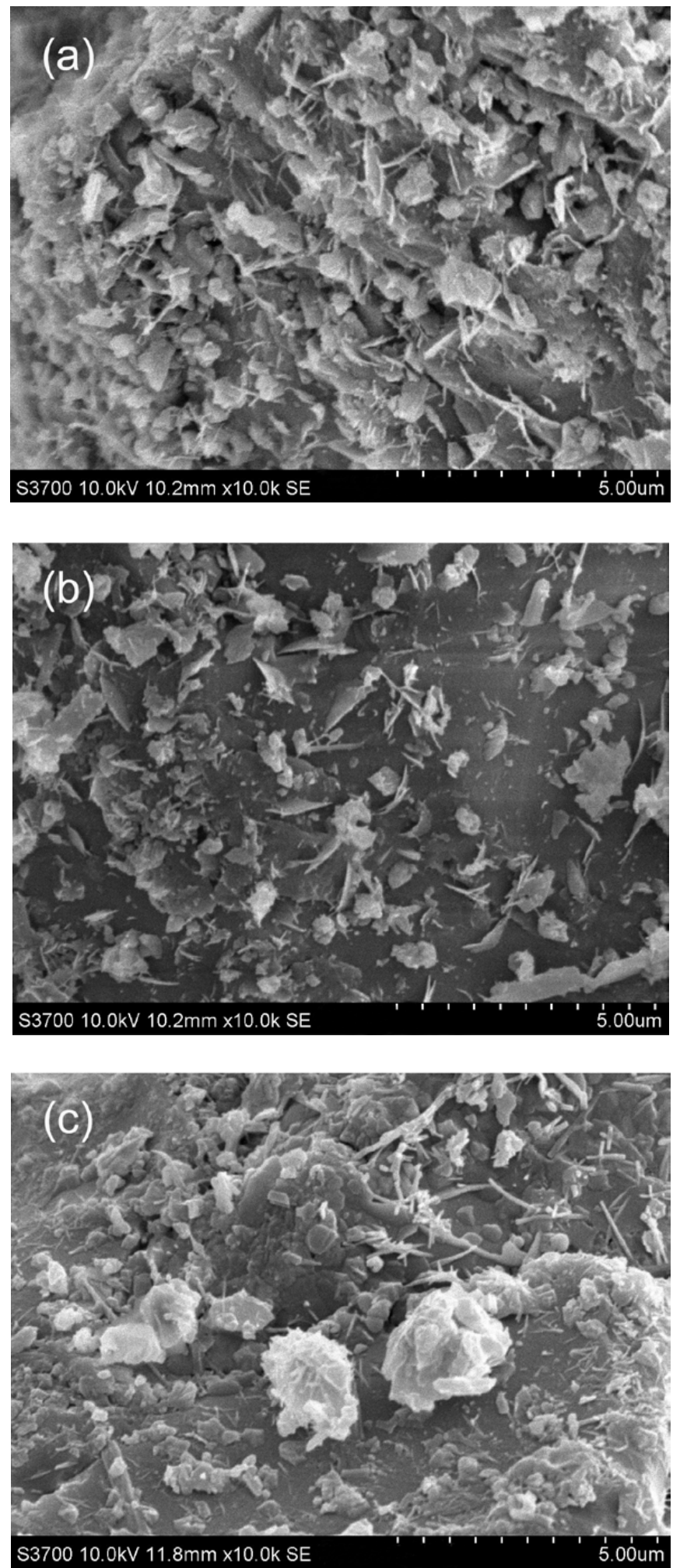

Figure 4: SEM micrographs of the cement clinkers with the replacement of different AWM in raw meals: (a) $0 \%$, (b) $2.5 \%$, (c) $5.0 \%$. 


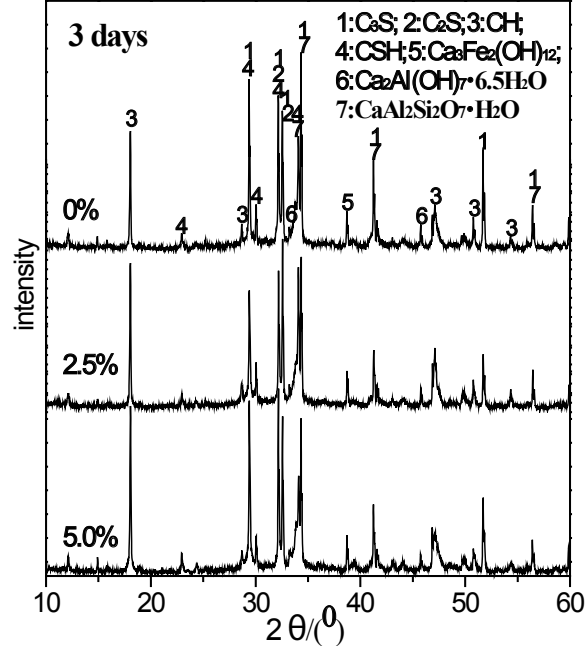

Figure 5: X-raw diffraction patterns for hydrated cement clinker pastes for 3 days.

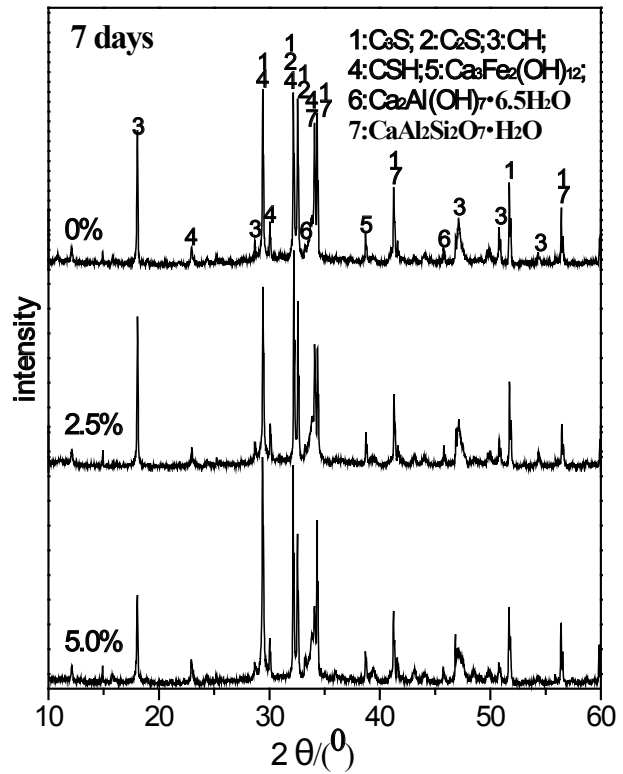

Figure 6: X-raw diffraction patterns for hydrated cement clinker pastes for 7 days.

in Table 3. The results showed that the initial setting time and final setting time of the OPC phase were $140 \mathrm{~min}$ and $196 \mathrm{~min}$, respectively, while the other three cement mortars with AWM replacements at 0 , 2.5 and $5.0 \%$ in raw meal were $145-202,139-195$ and $140-193 \mathrm{~min}$, respectively. It indicated that the initial and final setting times of cement mortars, which had AWM replacements in raw meal, were slightly short than that both of the plain paste and the OPC paste. The reason for the shorter setting times might be attributed primarily to the change contents of $\mathrm{C}_{3} \mathrm{~S}$ in the clinkers [9], because the $\mathrm{C}_{3} \mathrm{~S}$ phase in OPC clinker and those clinkers with AWM replacements were higher than the plain phase.

Flexural and compressive strengths of the pastes and OPC paste after curing ages at 3-28 days also were shown in Table 2 . It could be seen that the flexural and compressive strengths of the three pastes and OPC paste developed when the curing ages extended from 3 to 28 days. In comparison with the OPC and the plain paste, the results demonstrated that the flexural and compressive strengths of cement pastes were similar with the same conditions, although there had somewhat changes of the strengths. Those results might be responsible for the changes of the setting times in the process of hydration and the changes of compositions in the clinkers.

\section{Cement clinker paste hydrates}

To confirm the results discussed above, tests of the hydration process for the clinker pastes were carried out. The hydration products of the three clinker pastes, at the various curing times (3-28 days), could be seen through the XRD patterns in figure 5, 6 and 7, respectively. It revealed that the higher peaks for $\mathrm{Ca}(\mathrm{OH})_{2}$, calcium silicate hydrate $(\mathrm{CSH})$ and calcium aluminum hydrates $(\mathrm{CAH})$ could be identified in all the curing times, except for the peaks of $\mathrm{C}_{3} \mathrm{~S}$ and $\mathrm{C}_{2} \mathrm{~S}$. Moreover, it could be observed from these figures that the degrees of hydration for the three clinker pastes were increased as the amount of AWM replacement increased in raw meal, when curing age extended from 1 to 28 days. In addition, higher peaks of $\mathrm{Ca}(\mathrm{OH})_{2}$ in figure 5 suggested a faster hydration process for the clinker pastes than the plain clinker paste. It was reported [14] that CSH was formed by consuming $\mathrm{Ca}(\mathrm{OH})_{2}$, figure 6 and 7 showed that the peaks of $\mathrm{CSH}$ for sample clinker pastes were higher than the plain clinker paste, while the peaks

\begin{tabular}{|l|l|l|l|l|l|l|l|l|}
\hline \multirow{2}{*}{$\begin{array}{l}\text { Soda residue } \\
\text { content (\%) }\end{array}$} & \multicolumn{2}{l|l}{$\begin{array}{l}\text { Setting times } \\
\text { (hrs : min) }\end{array}$} & \multicolumn{3}{l|l}{$\begin{array}{l}\text { Flexural strengths } \\
\text { (MPa) }\end{array}$} & \multicolumn{3}{l}{$\begin{array}{l}\text { Compressive strengths } \\
\text { (MPa) }\end{array}$} \\
\cline { 2 - 9 } & Start & Final & $3 \mathrm{~d}$ & $7 \mathrm{~d}$ & $28 \mathrm{~d}$ & $3 \mathrm{~d}$ & $7 \mathrm{~d}$ & $28 \mathrm{~d}$ \\
\hline OPC & $2: 20$ & $3: 16$ & 6.10 & 7.55 & 9.65 & 30.25 & 41.35 & 61.26 \\
\hline 0 & $2: 25$ & $3: 22$ & 6.02 & 7.56 & 9.55 & 31.22 & 43.25 & 62.15 \\
\hline 2.5 & $2: 19$ & $3: 15$ & 6.10 & 7.45 & 9.68 & 33.25 & 43.75 & 61.55 \\
\hline 5.0 & $2: 20$ & $3: 13$ & 6.15 & 7.55 & 9.60 & 32.45 & 43.80 & 62.05 \\
\hline
\end{tabular}

Table 3: Setting times, Flexural strengths and Compressive strengths of plain and cement mortars

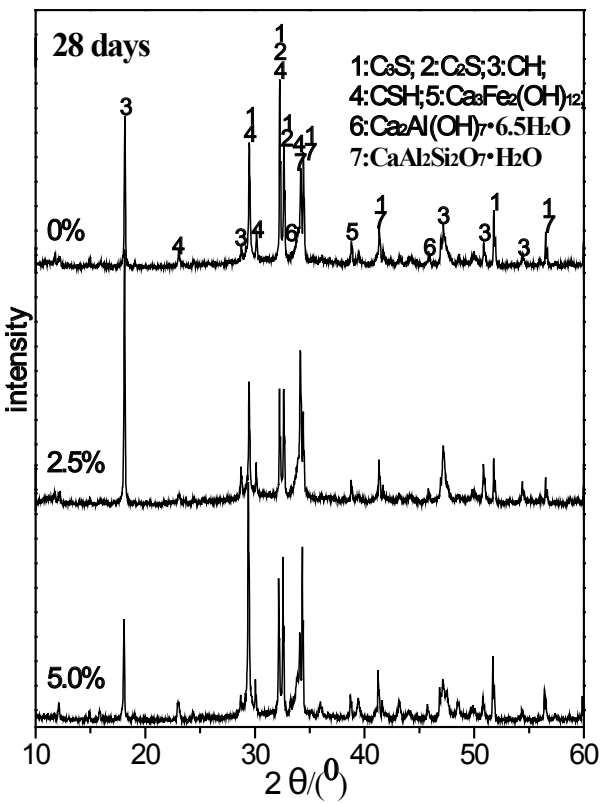

Figure 7: X-raw diffraction patterns for hydrated cement clinker pastes for 28 days. 
of $\mathrm{Ca}(\mathrm{OH})_{2}$ decreased. This was primary duo to the increased contents of $\mathrm{C}_{3} \mathrm{~S}$ in the clinkers, so the amount of $\mathrm{Ca}(\mathrm{OH})_{2}$ was formed at early curing ages, and then the hydration of the clinker pastes somewhat increased and the rate of the strength development was enhanced at the later curing ages.

\section{FTIR specimen analysis}

FT-IR is one of the versatile tools in predicting the degree of hydration and monitoring the dynamics of changes during the hydration reaction in Portland cement [15-17]. In this study, in order to confirm the result of the hydrates, FT-IR was used to evaluate the clinker pastes when AWM was added as substitutes in the raw meal. The FTIR spectra of the cement clinker pastes were presented in figure 8,9 and 10, respectively. It showed the appearance of bands at 3644, $3450,1638,1425,975,873$ and $460 \mathrm{~cm}^{-1}$. According to the spectra of hydrated products had been reported, the absorption band at $3644 \mathrm{~cm}^{-1}$ was due to the stretching vibration of $v(\mathrm{OH})$ of $\mathrm{Ca}(\mathrm{OH})_{2}$, which was formed as silicate phases in the cement dissolved [17]. Strong peak at $3450 \mathrm{~cm}^{-1}$ may be due to $-\mathrm{OH}$ or $\mathrm{H}_{2} \mathrm{O}$ stretching vibration. The strong peaks at $973 \mathrm{~cm}^{-1}$ indicated the shifting of anhydrous phase and /or (Si$\mathrm{O})$ absorption bands of $\mathrm{C}_{2} \mathrm{SH}_{2}$ and C-S- $\mathrm{H}$ phases stretching vibrations

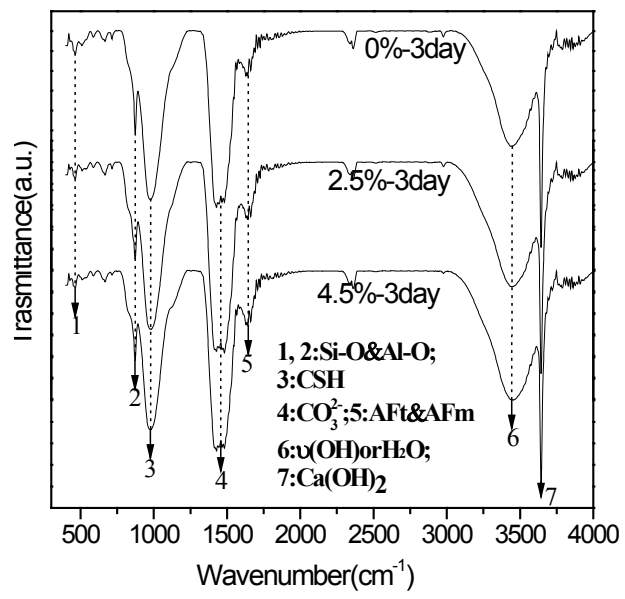

Figure 8: FT-IR spectra of cement clinkers specimens cured for 3 days.

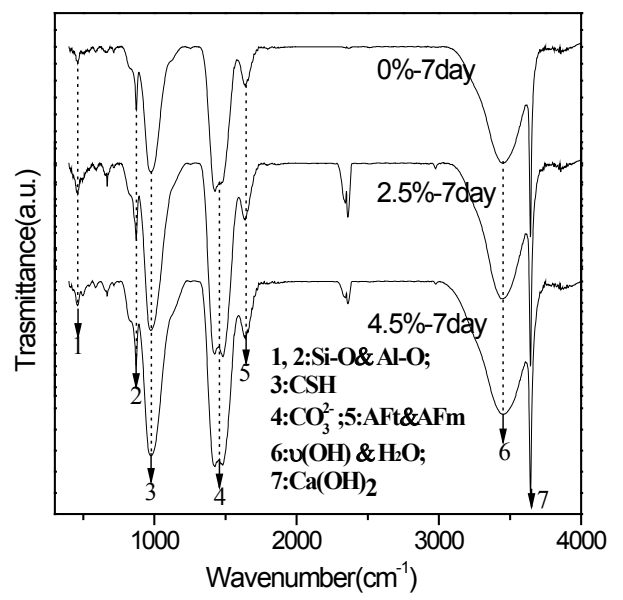

Figure 9: FT-IR spectra of cement clinkers specimens cured for 7 days.

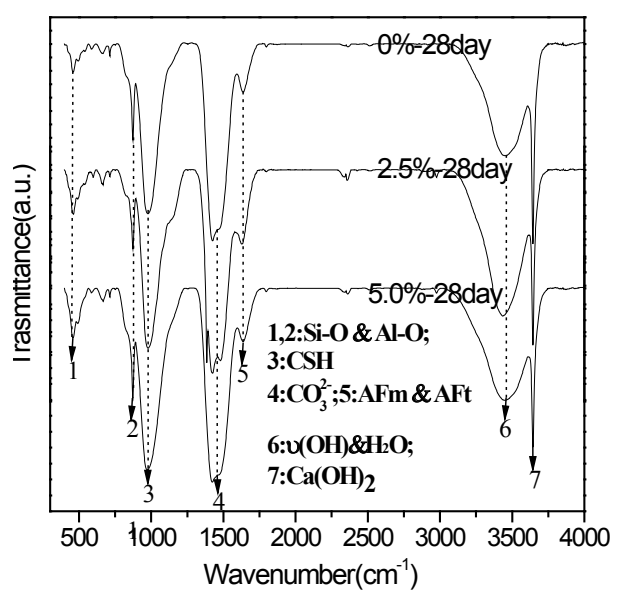

Figure 10: FT-IR spectra of cement clinkers specimens cured for 28 days.

[18-20]. The peaks at $1637 \mathrm{~cm}^{-1}$ were due to the presence of calcium sulphate in the form of ettringite (mono and tri-sulphate) in the cement $[19,20]$. The peaks at $1425 \mathrm{~cm}^{-1}$ was due to the presence of $\mathrm{C}=\mathrm{O}$ stretching vibration $[21,20]$. The peaks at 460 and $873 \mathrm{~cm}^{-1}$ might be due to the $\mathrm{Si}-\mathrm{O}$ and $\mathrm{Al}-\mathrm{O}$ stretching vibration of silicate and aluminate groups [19].

As compared to the infrared absorption band of hydrated cement clinkers, it showed that all the hydrated products were similar in the curing ages of 1-28 days. However, it could be seen in the figures 8 and 9 , the peaks for the hydrated products $\left(\mathrm{CO}_{3}{ }^{2-}\right.$ and $\left.\mathrm{CSH}\right)$ of the clinker pastes, which had been added AWM as substitutes in the raw meal, were somewhat higher than the plain clinker paste. In contrast, after 28 days (Figure 10) of curing, the differences disappeared. This indicated that the using the AWM as substitutes in the raw meal might increase the ratio of the hydration for the clinker pastes.

\section{Conclusions}

The objective of this study was to investigate the possibility of disposing alkaline white mud by using the cement kiln of the cement plant and evaluating its effects on the properties of cement-based materials by adding different percentages of alkaline white mud as substitutes in raw meal. Based on the above results and discussion, it was found that there was feasibility of using AWM as substitutes in raw meal to produce OPC cement. The contents of the magnesium oxide, Sulphur trioxide and chloride ions, which might have an influence on the property of cement, were much less than the limitation value of the standards. However, the contents of free lime increased with the contents of AWM addition. Moreover, the addition of AWM in raw meal increased the content of $\mathrm{C}_{3} \mathrm{~S}$ phase in the clinker, and it somewhat decreased the setting times and enhanced the strengths of the cement pastes in the early curing ages. Furthermore, this research only had been carried out in the laboratory, if it was applied to practical production, more research needed to be done.

\section{Acknowledgement}

The authors wish to gratefully acknowledge the financial support from the Key Science and Technology Research Project from Peoples Republic of China (Grant No. 2008BAE64B05) and would like to acknowledge assistance from staffs who provided full support to this study. The kind suggestions from the anonymous reviewers are greatly acknowledged.

\section{References}

1. Shi L, Luo H (2009) Preparation of soil nutrient amendment using white mud 
Citation: Zhou S, Lin Y, Zhao J, Zeng S, Zhou J (2012) Utilization of the Alkaline White Mud as Cement-Based Materials for the Production of Cement. J Civil Environment Engg 2:108. doi:10.4172/2165-784X.1000108

Page 7 of 7

produced in ammonia-soda process and its environmental assessment. T Nonferr Metal Soc 19: 1383-1388.

2. Kasikowski T, Buczkowski R, Lemanowska E (2004b) Cleaner production in the ammonia-soda industry: an ecological and economic study. J Environ Manage 73: 339-356.

3. Steinhauser G (2008) Cleaner production in the Solvay Process: general strategies and recent developments. J Clean Prod 16: 833-841.

4. Choy KKH, Ko DCK, Cheung WH, Fung JSC, Hui DCW, et al. (2004) Municipal Solid Waste Utilization for Integrated Cement Processing with Waste Minimization: A Pilot Scale Proposal Process. Saf Environ 82: 200-207.

5. Mijno V, Martin F, Bollinger JC, Catalan LJJ (2007) Stabilization-Solidification Process: Comparison of Synthetic Sludge and Volcanogenic Massive Sulphide Tailings. Process Saf Environ 85: 260-264.

6. Viguri J, Andrés A, Ruiz C, Irabien A, Castro F (2001) Cement-Waste and ClayWaste Derived Products from Metal Wastes: Environmental Characterization. Process Saf Environ 79: 38-44.

7. Kasikowski T, Buczkowski R, Dejewska B, Peszynska-Bialczyk K, Lemanowska E, et al. (2004a) Utilization of distiller waste from ammonia-soda processing. J Clean Prod 12: 759-769.

8. Lin KL, Lin DF, Luo HL (2009) Influence of phosphate of the waste sludge on the hydration characteristics of eco-cement. J Hazard Mater 168: 1105-1110.

9. Lin KL, Chiang KY, Lin CY (2005) Hydration characteristics of waste sludge ash that is reused in eco-cement clinkers. Cement Concrete Res 35: 1074-1081.

10. Lin KL, Lin CY (2005) Hydration characteristics of waste sludge ash utilized as raw cement material. Cement Concrete Res 35: 1999-2007.

11. Lee TC, Li ZS (2010) Conditioned MSWI ash-slag-mix as a replacement for cement in cement mortar. Constr Build Mater 24: 970-979.
12. Gao XB, Wang W, Ye TM, Wang F, Lan YX (2008) Utilization of washed MSW fly ash as partial cement substitute with the addition of dithiocarbamic chelate. J Environ Manage 88: 293-299.

13. Ito R, Dodbiba G, Fujita T, Ahn JW (2008) Removal of insoluble chloride from bottom ash for recycling. Waste Manage 28: 1317-1323.

14. Wang KS, Lin KL, Huang ZQ (2001) Hydraulic activity of municipal solid waste incinerator fly-ash-slag-blended eco-cement. Cement Concrete Res 31: 97103.

15. Creighton AT, Zhengxian Y, Peterson MM, Xianming S (2009) Effect of styrene-butadiene rubber latex on the chloride permeability and microstructure of Portland cement mortar. Constr Build Mater 23: 2283-2290.

16. Mollah MYA, Yu WH, Schennach R, Cocke DL (2000) A Fourier transform infrared spectroscopic investigation of the early hydration of Portland cement and the influence of sodium lignosulfonate. Cement Concrete Res 30: 267-273.

17. YImen R, Jaglid U, Steenari BM, Panas I (2009) Early hydration and setting of Portland cement monitored by IR, SEM and Vicat techniques. Cement Concrete Res 39: 433-439.

18. Geng Ying L, Pei Ming W, Xiaohua Z (2005) Mechanical behavior and microstructure of cement composites incorporating surface-treated multiwalled carbon nanotubes. Carbon 43: 1239-1245.

19. Rai US, Singh RK (2005) Effect of polyacrylamide on the different properties of cement and mortar. Mat Sci Eng A-struct 392: 42-50.

20. Singh NK, Mishra PC, Singh VK, Narang KK (2003) Effects of hydroxyethy cellulose and oxalic acid on the properties of cement. Cement Concrete Res 33: 1319-1329.

21. Farooque KN, Yeasmin Z, Halim ME, Mahmood AJ, Mollah MYA (2010) Effect of Carboxymethyl Cellulose on the Properties of Ordinary Portland Cement. Bangladesh J Sci Ind Res 45: 1-8. 